\title{
"We Are in Between": Case Studies on the Protection of Somalis Displaced to Kenya and Egypt during the 2011 and 2012 Drought
}

\author{
Vikram Kolmannskog ${ }^{1}$ \\ ${ }^{1}$ Norwegian Refugee Council \\ Correspondence: Vikram Kolmannskog, Frydenlundgata 4, 0169 Oslo, Norway. Tel: 47-9110-0561. E-mail: \\ post@ vikramkolmannskog.no
}

Received: September 27, 2013 Accepted: October 21, $2013 \quad$ Available online: October 31, 201x

doi:10.11114/ijsss.v2i1.263

URL: http://dx.doi.org/10.11114/ijsss.v2i1.263

\begin{abstract}
Natural hazard-related disasters, including those associated with climate change, displace millions of people. Those displaced across international state borders face particular challenges with regards to legal status and rights protection. This paper discusses to what extent, and how, this group of displaced people are protected, and indicates how their protection can be further strengthened. The discussion draws on case studies of Somalis displaced to Kenya and Egypt during the 2011 and 2012 drought. Appreciation of the contextual vulnerability in disasters and the multi-causality of displacement can, and should, inform the interpretation of the refugee concept(s). In Kenya, for example, all Somalis were given refugee status on a prima facie group basis due to the presence of generalised violence as well as drought in their home country. In Egypt, the decision-makers operated with a different understanding and practice, and many Somalis risked falling outside the refugee definition(s). Beyond getting a formal refugee status recognition, however, there may also be protection issues such as restrictions on inter alia the right to work and freedom of movement, as well as issues related to operational capacity and resources such as lack of shelter and security. A series of extra-legal factors must be given due consideration both to ensure that the protection capacity of existing law is employed to its fullest and that new legal and policy developments become effective.
\end{abstract}

Keywords: refugee, Somalis, drought, climate change, law, protection, Kenya, Egypt

\section{Introduction}

An emerging body of research indicates that disasters associated with climate change influence human mobility, including forced displacement (Foresight, 2011; Intergovernmental Panel on Climate Change [IPCC], 2012). Over five years from 2008 to 2012, around 144 million people were forced from their homes by sudden-onset disasters (Internal Displacement Monitoring Centre, 2013). The vast majority of this displacement, 83 per cent, was triggered by climate-related disasters such as floods, storms and wildfires (ibid.). In addition, many people are affected by slow-onset disasters such as drought. Throughout 2011 and 2012, large numbers of destitute agro-pastoralists and others fled drought and violent conflict in Somalia. Many ended up in neighboring Kenya. Some travelled further to countries such as Egypt.

In these cases of people displaced to another country in the context of climate change and natural hazard-related disasters, humanitarian and international law experts have identified a protection gap in international law (Inter-Agency Standing Committee [IASC], 2008). Allegedly, the majority will not qualify as refugees or any other particularly protected category of persons. Human rights will only provide minimal protection (ibid.). Certain initiatives to address this protection gap exist, including the Nansen Initiative, a state-driven, multi-stakeholder process (Nansen Initiative, 2013). Regional consultations are planned to take place over the course of 2013 and 2014, including in the Horn of Africa. The outcomes will feed into a global consultative meeting planned for 2015 when states and other stakeholders will agree on a "protection agenda". This agenda may include a common understanding of the issue; good practices and tools for the protection of the displaced; key principles on inter-state/international cooperation, standards of protection of displaced people, and operational responses; recommendations on the respective roles and responsibilities of relevant actors; and an action plan for follow-up (ibid.). 
In light of such processes, this paper discusses to what extent, and how, this group of displaced people are protected, and indicates how their protection can be further strengthened. The discussion draws on case studies of Somalis displaced to Kenya and Egypt during the 2011 and 2012 drought. Kenya is the African country with the largest Somali displaced community, hosting more than 500000 Somalis (Lindley, 2011). Egypt was chosen partly due to its status as a destination and transit country and partly due to differences from Kenya in terms of geographical distance, legal frameworks, conditions for Somalis in general and the socio-political context more broadly. Field visits to Dadaaband Nairobi in Kenya and Cairo in Egypt were undertaken in May 2012. At the time of the visits, Kenya had troops in Somalia and was experiencing security incidents labelled as terrorist attacks and was planning to have elections in a year's time. The situation in post-revolutionary Cairo was characterised by domestic tension and change. While Somali refugees were very much part of the political discourse in Kenya, they were not so much the focus for Egyptians. The study included semi-structured individual interviews and discussion groups. In addition to interviewing Somalis displaced during the drought, a desk-study and other key stakeholder interviews were undertaken, including interviews with the United Nations High Commissioner for Refugees (UNHCR) and humanitarian and development agency staff, government officials, and local, Kenyan nationals.

The methodology as well as the findings are described in more detail elsewhere (Kolmannskog, 2012b). This paper aims to present some of the main socio-legal insights from the ground along with more doctrinal and political considerations of law in order to discuss how law is applied as well as how it could/should be in order to protect those displaced. First, there are short introductions to the legal concept(s) of refugee and the situation in Somalia. The paper then proceeds to highlight certain main findings and discusses these in light of existing theory and research.

\section{The Refugee in 1951 and 1969}

While refugees in popular usage may refer to all displaced people, the legal definition is rather narrow. According to article 1 A of the 1951 Convention relating to the Status of Refugees as modified by the 1967 Protocol (which deleted geographic and temporal limitations), a refugee is a person who

"owing to a well-founded fear of being persecuted for reasons of race, religion, nationality, membership of a particular social group, or political opinion, is outside the country of his nationality, and is unable, or owing to such fear, is unwilling to avail himself of the protection of that country $[\cdots]$ "

The Convention was created mainly by European males for the problems of European males after the Second World War, and it is a product of its time, place and creators (Kolmannskog, 2012a). After assessing the different grounds and other criteria of the 1951 Convention, scholars conclude that those displaced in the context of climate change and natural hazard-related disasters cannot be refugees (Falstrom, 2001) - or at least that the great majority cannot qualify as refugees (IASC, 2008).

Later, regional instruments have developed different refugee definitions. In Africa, the 1969 African Union Convention governing the Specific Aspects of Refugee Problems in Africa includes those fleeing "events seriously disturbing public order". Most states have interpreted this to cover situations of generalised violence whilst excluded natural hazard-related disasters (Rankin, 2005). However, it is not obvious from the wording that disasters cannot also be covered.

Those who qualify as refugees are entitled to a series of rights laid out in the conventions. These include protection from refoulement - being returned to an area where their life and freedom would be threatened - and a series of political, economic and social rights.

Kenya is a signatory to the 1951 Convention and its 1967 Protocol as well as the 1969 African Union Convention. There is also domestic legislation such as the 2006 Refugees Act and the 2011 Refugees Bill. Kenyan authorities have delegated most matters to UNHCR, including refugee status determination, but are increasingly assuming responsibilities. Egypt is also party to the 1951 Refugee Convention, its 1967 Protocol as well as the 1969 African Union Convention; and, registration, documentation and refugee status determination are carried out by UNHCR.

\section{Situation in Somalia}

Africa is one of the most vulnerable continents to climate change and has the greatest lack of adaptive capacity (IPCC, 2007). Average rainfall is estimated to increase in the East and Horn of Africa (ibid.), but this does not necessarily mean fewer droughts. For example, there may still be long, dry periods with erratic and intense rainfalls. In fact droughts have become more frequent and intense in recent years. The UNHCR as well as the International Organisation for Migration have observed that environmental considerations are increasingly 
affecting the movement of people in this region (International Organisation for Migration, $2000 \& 2005$, in Leighton 2006; Afifi et al., 2012).

Somalia is mainly semi-arid to arid with irregular rainfall and moderate temperatures in the north and high temperatures in the south. Natural hazards include recurring drought, frequent dust storms over the eastern plains in summer, and floods during the rainy season. Pressing environmental issues include the use of contaminated water, which contributes to human health problems, deforestation, overgrazing, soil erosion and desertification. Due to the climate and environmental issues as well as violent conflict, poverty and other factors, Somalia is considered to be among the countries most vulnerable to climate change and natural hazards (Global Humanitarian Forum, 2009).

While most countries in the East and Horn of Africa were badly affected by drought in 2011 and 2012, the situation was almost beyond imagination in Somalia with famine being declared in several regions (Food Security and Nutrition Analysis Unit [FSNAU] \& Famine Early Warning Systems Network [FEWSNET], 2011). It was the most severe humanitarian crisis in the world in 2011 and Africa's worst food security crisis since Somalia's 1991-92 famine.

\section{Multi-causal Disasters and Displacement}

As already described many scholars and experts dismiss the applicability of the refugee concept(s) in the context of climate change and natural hazard-related disasters. There seems to be a misconception that people who flee in these circumstances, flee on merely "natural" - as opposed to political and other relevant - grounds. This must be challenged. There is an increasing recognition that so-called natural disasters are not entirely "natural". First, there is growing agreement that there is a human factor in creating climate change, which in turn influences certain natural hazards (IPCC, 2012). Second, there are human factors involved in all disasters - including those not related to climate change - as the degree of disaster depends on vulnerability and the (lack of) action from governments and others before, during and after a natural hazard (United Nations International Strategy for Disaster Reduction, 2009). Contextual vulnerability is considered to be influenced "not only by changing biophysical conditions, but by dynamic social, economic, political, institutional and technological structures and processes; i.e. contextual conditions" (O'Brien et al. 2007, p. 76).

Most human mobility experts - including those focusing on climate change and natural hazard-related disasters emphasise that drivers interact and that human mobility is multi-causal (Foresight, 2011). In the context of these disasters, who leaves, who returns, and when they return depends not only on the environmental factor but also on the social, economic, political and demographic circumstances (ibid.). The concepts of multi-causality in movement and contextual vulnerability in disasters can be considered closely related.

Doctrinal lawyers who are concerned with what the law is (rather than how it is applied on the ground), are too quick in dismissing the relevance of the refugee concept. An appreciation of the contextual vulnerability in disasters and multi-causality of displacement can, and should, inform a different and relevant refugee interpretation. This happened in Kenya, as we will see in the next section, an example of good practice for others to follow.

\section{Prima Facie Refugees in Kenya}

Due to the generalised violence in South Central Somalia, the Kenyan government and UNHCR Kenya consider that all people coming from this area are prima facie refugees according to the African Union Convention definition. This is a position that Kenya shares with other countries in the region surrounding Somalia.

In 2011, the government of Kenya (2011) stated that, "[t]he current influx of refugees into Kenya is of Somalis seeking food and not people running away from violence. The refugees are coming into Kenya to get food due to the severe drought situation in Somalia." The Refugee Consortium of Kenya (2012) believes that the large numbers of people coming for reasons that are not recognised in any of the refugee conventions can undermine the prima facie status in the long run.

On the other hand, it is worth noticing that the official statement from the government of Kenya (2011) employed the refugee label for this group as well, and claimed that, "Kenya has welcomed all refugees and assisted them." One could also argue that many of the Somalis were in fact traditional refugees because violent conflict and persecution played a role in their displacement.

In Somalia, it is difficult to separate drought and conflict. "I believe drought and civil war are twins that have come together to plague my country," said Ahmed (32). A statement by Abdinoor (49), community leader in one of the refugee settlements in Dadaab, was also representative of many people's views, "When there is only a drought, the government or international agencies will come in and give assistance so you can cope. When there is a conflict, 
agencies cannot come and help. People fled because there was no assistance, and the reason was the conflict."

While many displaced Somalis believed that natural hazard-related disasters are the will of God, all interviewees were also clear about the human factor. Previous studies also describe how state failure and violent conflict exacerbate natural hazard-related disasters and reduce people's adaptive capacity (Kolmannskog, 2010; Afifi et al, 2012). The Food Security and Nutrition Analysis Unit (FSNAU) and the Famine Early Warning Systems Network (FEWSNET) also claimed that the lack of humanitarian assistance and access was one of the main causes of the famine (FSNAU \& FEWSNET, 2011). Humanitarian assistance was extremely limited until September due to inadequate funding and intervention by the international community, and armed groups severely restricting humanitarian access.

This appreciation of multi-causality and interaction of drought and violent conflict was clear in an interview with a Department of Refugee Affairs official: "In 2011 most people came due to drought and the fighting. Since there are two reasons, we accept them. The fighting is the reason considered." Kolmannskog (2010) and Zetter (2011) also found that the refugee conventions worked as protection instruments for disaster-related displacement in Kenya. Applying the refugee concept in a context where climate change, natural hazard-related disasters, violent conflict and/or persecution interact is perfectly in line with the refugee definitions in the international and regional treaties. Since vulnerability and displacement depend not merely on the "natural" factors, this may involve a larger number of people than some doctrinal lawyers and others immediately think.

\section{Adjusting Narratives in Egypt}

In Egypt, as in most countries that are not immediate neighbours to Somalia, there is individual refugee status determination rather than prima facie group determination. Each individual must meet all criteria in the refugee definitions, including showing that the reason for the displacement is persecution, generalised violence or another reason recognised in law.

This means that some people adjust or highlight certain parts of their narratives. "People would not come to the office and say that they came due to drought," said a UNHCR interviewee. "I told them how I lost family members in the drought and fighting. Now I am waiting to have my case decided," said Ahmed (32). At the time of the field visit, the status of several of the interviewees was undecided and they were in a state of waiting.

Because Somaliland is considered relatively peaceful, people originating there would in theory fall outside the refugee definitions. All Somalis interviewed for this study said they were from South Central Somalia. "I am sure we have recognised many of the Somalilanders as refugees," informed the UNHCR interviewee. "There have even been conflicts within the Somali community because they are seen as taking the resettlement places from other Somalis. But the Somalis keep it to themselves rather than taking it to UNHCR and spoiling the whole group's opportunities."

After the recent political changes in Libya many refugees and migrants fled the country, some to Egypt. Among them there was also a group of Somalilanders who are not recognised as refugees. "They talk about the drought a lot and say that they should not be returned on humanitarian grounds. Originally they said they were from South Central Somalia. When we found out that this was not correct, they admitted that they were from Somaliland and could not go home due to the drought and lack of economic opportunities," said the UNHCR interviewee. "We have said to them that if Egypt allows them in, ok. Otherwise they have to go home. We can understand that they don't want to go home, but no resettlement country would take them either. They would rather go back to Libya or try to get smuggled elsewhere than go back I think."

While some Somalis in Egypt may also get refugee status due to the multi-causality of disasters and displacement, the test is more demanding than in prima facie refugee status determination, and many Somalis risk falling outside the refugee definition. Only certain facts are relevant to law, such as generalised violence and persecution in the case of refugee law, and it is completely legitimate to highlight these aspects of a person's narrative. In some cases people go further and lie in order to get a status recognised by law. That some people who have fled in the context of climate change and natural hazard-related disasters feel compelled to lie in order to get protection, and many fail to get the protection, may indicate that there are weaknesses with the current refugee regime. This seems particularly to be the case where the interacting factors in disasters and displacement do not so clearly include factors that are recognised in refugee law, such as generalised violence or persecution. As already mentioned, however, there is no good objection against "events seriously disturbing public order" in the African Union Convention also covering instances of extreme natural hazard-related disaster situations. It is not so much the law that would need to be developed as the African states' understanding and practice. 


\section{Actual Protection beyond Formal Refugee Status}

There is much focus among lawyers and policy-makers on whether those displaced in the context of climate change and natural hazard-related disasters are covered by the refugee definition or not. But we also need to go beyond the formal status question to see whether protection is effective or not.

Even though Somalis arriving in Kenya were considered refugees, they suffered from the lack of, and sometimes direct violations of, effective refugee rights and human rights. The Kenyan-Somali border has been officially closed since 2007, and several Somalis experienced difficulties in crossing the border. The Kenyan government argues that this is needed because of the armed conflict in the neighbouring country and the risk of combatants moving into Kenya. Yet, the Kenyans cannot patrol the whole length of the border and it is highly permeable. The effect of the border measures is mainly that they make the journey longer and more hazardous for displaced Somalis, sometimes resulting in loss of life (see also Refugee Consortium of Kenya, 2012).

Kenya restricts refugees' freedom of movement and contains them in camps run by UNHCR and NGOs in remote areas of the country. In these crowded camps the interviewees reported particular challenges related to shelter, security and gender-based violence. Highlighted was also the lack of training and livelihood opportunities. Formally, their right to work is restricted in Kenya. "There are not many opportunities for livelihood interventions," said a UNHCR interviewee. "Sadly, Kenya equates self-reliance with local integration, and they don't want that. But self-reliance will be helpful also for a potential return." Still, some refugees have animals and small plots of land - and this is tolerated in Dadaab- others have businesses, and still others work for the agencies in the camps as "incentive workers" on a lower salary than that given to Kenyans. Despite the grim prospects of getting a job, education and training could also provide some purpose and hope for the future. "My children are now in school and get an education so that they can work. This is my hope for the future," said Fatima Y. (30).

Most of the challenges mentioned are similar to those of many other refugees in Dadaab and elsewhere in large camps and not particular to those who have fled in the context of climate change and natural hazard-related disasters.

Egypt has also made important reservations against several of the social and economic rights in the refugee conventions. Refugees have limited access to work, health services and education and no right to permanent residency. The interviewees in Cairo reported particular challenges related to shelter, work and mental health. "One of the main challenges is that all of us are very depressed," said Ahmed (32). He identified both the drought and their current situation as causes. "Every time I hear the word drought I feel miserable. I felt depressed and was unable to speak. I was on the verge of a mental breakdown. Here we are in between. If we try to go to Europe, we die in the Mediterranean. In Somalia we die of conflict and drought."

Beyond getting a formal refugee status, people displaced in the context of climate change and natural hazard-related disasters may also face challenges related to formal law such as limitations on the right to work, and challenges related to operational capacity and resources such as lack of shelter and security. The case studies showed that any law and policy attempting to address displacement in the context of climate change and natural hazard-related disasters should, in addition to granting a formal (temporary) status, include provisions allowing entry to the country and securing basic rights including shelter, physical security including against gender-based violence, food security, work, education and health.

\section{Solutions to the Displacement}

The refugee regime operates with three solutions to displacement: return, local integration and resettlement to another country. Often return has been seen as the preferable solution by both the hosting state and UNHCR.

"If the situation improves in Somalia, the only solution is voluntary repatriation," said a Kenyan Department of Refugee Affairs interviewee. But at the time of the study, the situation was still too unstable for mass repatriation, and most refugees were not willing to return (see also Lindley, 2011; Refugee Consortium of Kenya, 2012).A stable government and peace was a prerequisite for all interviewees. All of the interviewees in Dadaab still had some land in Somalia that relatives or neighbours looked after. Many had sold their farm tools and animals and would need assistance in obtaining such resources. Improved access to water through for example boreholes and irrigation was also mentioned. For many, it was important that they or their children also had some new skills before returning. As Haug (2002, p. 71) writes, "The return process is not about going home or back in time to regain something that once existed, it creates an entirely new situation."

In September 2012 clan elders appointed members to a new parliament replacing the Transitional Federal Parliament, as part of an agreed transition plan. In addition, armed groups have been driven out of important cities and areas and some level of peace and law and order has been restored. This - in addition to harsher 
conditions in camps and urban areas in Kenya - has resulted in thousands of Somalis returning home since the end of 2012 (Regional Mixed Migrations Secretariat, 2013).

Kibreab (1989, p. 469) defines integration as the "economic, social, and cultural process by which the refugees become members of the host society on a permanent basis." Some of the refugees who live in Dadaab have lived there for 20 years. As already mentioned, some people work despite the lack of formal rights. The local Kenyans are also ethnic Somalis and there are inter-marriages. While the camps have had adverse effects on the local natural environment and local livelihoods, research shows that the refugees and camps have had an overall positive economic effect on the historically marginalised area (Enghoff, M. et al., 2010). Lindley (2011, p. 41) suggests that, "Rather than trying to 'compensate' host communities to prevent conflict, a better approach would be to adopt wider development approaches targeting refugee-hosting areas." In order to further local integration, Lindley recommends, "Options for piecemeal approaches (i.e. identifying eligible subgroups such as very long-term refugees/qualified professionals) or gradual approaches to integration (i.e. identifying progressive pathways to fuller legal status, contingent on the fulfilment of particular conditions) merit exploration. A rather modest example would be the easing of work permit requirements. (p. 37)"

According to an NGO staff in Dadaab who was also a native of the area, there was no question about it: "Of course local integration is happening. It's just that UNHCR and the government don't want to talk about it." It may be that the relevant state law and policy has a "symbolic function" (Aubert, 1950; Mathiesen, 2005), that it is important for Kenya to officially say that local integration is not an option while many government officials and others at the same time know that gradual integration is happening and even tolerate this to some degree.

The resettlement process rests on a two-fold rationale (Lindley, 2011). Some refugees' protection may be better secured in a third country. Second, through resettlement, other countries share the international responsibility for protecting refugees. Kenya's position is to promote resettlement as long as return is not possible. With security concerns increasing, several Kenyans are questioning the wisdom of Kenya hosting so many Somalis. Several of the Somalis in both Dadaab and Cairo were hoping for resettlement or to somehow reach European and other developed countries. With the current anti-immigration sentiments in developing countries, there is less will to resettle, however. This does not stop people from trying to make it onwards on their own. Ahmed (32) felt that their current situation, being "in between", was part of the reason for their depression: "We are not sure if we will be resettled. We cannot continue living in Egypt. A friend of mine tried crossing from Libya over to Italy and died in the Mediterranean. Here we are in between. If we try to go to Europe, we die in the Mediterranean. In Somalia we die of conflict and drought. The solution is in the hands of God.” According to UNHCR (2012), more than 1500 irregular migrants or asylum seekers drowned or went missing in 2011 while attempting to cross the Mediterranean Sea.

\section{Some Extra-legal Factors That Matter}

A series of extra-legal factors influence whether the displaced people are protected or not. These must be given due consideration both to ensure that the protection capacity of existing law is employed to its fullest and that new legal and policy developments become effective.

The case studies have shown that refugee law was applied differently in Kenya and Egypt. This finding fits with Alexander Betts' notion of "regime stretching" and own findings:

"[I]t highlights how international regimes - as norms, rules, principles, and decision-making procedures governing a particular issue area - are not fixed and static entities that exist in abstraction in Geneva or New York $[\cdots]$ But rather they are dynamic and adaptive, and vary in their local and national manifestations. Sometimes, the norms (in this case, international refugee law) and the organization (in this case, the UNHCR) may stretch to address unforeseen circumstances but, at other times, they may not. The question is: When and why does this happen, and what does this mean in practical terms for whether (and, if so, how) the refugee regime needs to be reformed?" (Betts, 2010, p. 363).

While there is "regime stretching" in some cases, such as in Kenya, the case studies show how some people, such as the Somalilanders (and probably many other Somalis in Egypt), fall outside the refugee regime. According to interviewees and observations, important factors in Kenya's complex response included security concerns, UNHCR's relationship with the government, the extreme human suffering, a sense of African solidarity, lack of border control resources, the importance of the refugee camps for the development and power of the province and local politicians, etc.

During the most acute drought, UNHCR Egypt also proved to be proactive and pragmatic. First, they asked their headquarters in Geneva whether they should make any changes with regards to returns to Somaliland during the 2011 drought but did not get any clear advice. "Since Egypt does not deport people anyway, it was not so 
important to request a stop of deportations," said the UNHCR interviewee.

Furthermore, in the cases where the displaced fall outside the refugee concept(s) as it is currently interpreted, new law may not necessarily be needed. As already mentioned, there is no good objection against "events seriously disturbing public order" in the African Union Convention also covering instances of extreme natural hazard-related disaster situations. It is not so much the legal texts that would need to be developed as the African states' understanding and practice. With greater appreciation of the causes, effects and dynamics of disasters - as well as increasing climate change - such development is not unrealistic. In any case, this sort of development might be more realistic than getting states to change or adopt new international laws. Furthermore, adopting a new law may have "symbolic functions" more than anything else.

We see the "symbolic functions" of law in the case of European countries as well. A series of factors influence developed countries' will to accept refugees, including anti-immigration sentiments, and at the moment the will is little. Most European countries have elaborate legislation protecting refugees. In practice, however, many of them try - through visa regulations, interceptions and other measures - to make sure that as few asylum seekers as possible ever arrive in their countries to be able to enjoy this protection.

\section{Final Remarks}

Once we appreciate the multi-causality of disasters and displacement, the refugee concepts are still highly relevant in the context of climate change and natural hazard-related disasters. Rather than merely focusing on developing new laws - which may serve "symbolic functions" more than anything else - we should ensure that we utilize the full potential of existing law. This involves understanding that climate change and natural hazards often interact with recognised legal grounds such as generalised violence and persecution, and also developing the understanding and practice on "events seriously disturbing public order."

Both when considering current law and attempting to develop new solutions it is important to emphasize that effective protection is only possible with provisions allowing for entry, a (temporary) status, and basic rights including shelter, physical security including against gender-based violence, food security, work, education and health. And, we must consider extra-legal factors.

\section{Acknowledgments}

Special thanks goes to all the interviewees. Tine Ramstad at the Norwegian Refugee Council provided important support and input during all phases of the research. The research for this paper was made possible through the funding of the Norwegian Refugee Council and the Norwegian Ministry of Foreign Affairs. The author would also like to thank the editors and reviewers for helpful comments and assistance in working on the paper.

\section{References}

Afifi, T., Govil, R., Sakdapolrak, P., \& Warner, K. (2012). Climate change, vulnerability and human mobility: Perspectives of refugees from the East and Horn of Africa. Bonn: United Nations University.

Aubert, V. (1950). Priskontroll og rasjonering. En rettssosiologisk forstudie. Oslo: Skrivemaskinstua.

Betts, A. (2010). Survival Migration: A New Protection Framework, Global Governance, 16, 361-382.

Enghoff, B. Hansen, Umar, A., Gildestad, B., Owen, M., \& Obara, A. (2010). In Search of Protection and Livelihoods: Socio-economic and Environmental Impacts of Dadaab Refugee Camps on Host Communities. Nairobi: Royal Danish Embassy, the Republic of Kenya and the Norwegian Embassy. Retrieved fromhttp://www.ambnairobi.um.dk/NR/rdonlyres/8E1CC5EB-6B25-4531-A7E0-CDC32A0961B7/0/Final Report30092010.pdf

Falstrom, D. Z. (2001). Stemming the flow of environmental displacement: creating a convention to protect persons and the environment. Colorado Journal of International Environmental Law and Policy. Retrieved from http://www.uio.no/studier/emner/jus/jus/JUR5530/v07/undervisningsmateriale/environmental\%20refugees\%2 Oarticle.pdf

Food Security and Nutrition Analysis Unit \& Famine Early Warning Systems Network. (2011). Famine continues; observed improvements contingent on continued response. Nairobi/Washington Food Security and Nutrition Analysis Unit \& Famine Early Warning Systems Network. Retrieved from http://www.fsnau.org/in-focus/famine-continues-observed-improvements-contingent-continued-response

Global Humanitarian Forum. (2009). The Anatomy of a Silent Crisis. Geneva: Global Humanitarian Forum. Retrieved from http://www.preventionweb.net/files/9668_humanimpactreport1.pdf

Government of Kenya. (2011). Government of Kenya, Briefing on the Refugee and Drought Situation in the Country, 21 July. Retrieved fromhttp://reliefweb.int/node/435254 
Haug, R. (2002). Forced Migration, Processes of Return and Livelihood Construction among Pastoralists in Northern Sudan. Disasters, 26(1), 70-84. http://dx.doi.org/10.1111/1467-7717.00192

Inter-Agency Standing Committee. (2008). Climate Change, Migration and Displacement: Who will be affected? Submission to the United Nations Framework Convention on Climate Change, 31 October. Retrieved from http://unfccc.int/resource/docs/2008/smsn/igo/022.pdf

Internal Displacement Monitoring Centre. (2013). Global overview 2012: People displaced by disasters. Geneva: Internal Displacement Monitoring Centre.

Intergovernmental Panel on Climate Change. (2007). Fourth Assessment Report. Cambridge: Cambridge University Press.

Intergovernmental Panel on Climate Change. (2011). Summary for Policymakers. Intergovernmental Panel on Climate Change Special Report on Managing the Risks of Extreme Events and Disasters to Advance Climate Change Adaptation. Cambridge: Cambridge University Press.

Kibreab, G. (1989). Local Settlements in Africa: A Misconceived Option. Journal of Refugee Studies, 2(4), 468-490. http://dx.doi.org/10.1093/jrs/2.4.468

Kolmannskog, V. (2010). Climate change, human mobility, and protection: Initial evidence from Africa. Refugee Survey Quarterly, 113(19), 103-119. http://dx.doi.org/10.1093/rsq/hdq033

Kolmannskog, V. (2012a). Climate change, environmental displacement and international law. Journal of International Development, 24(8), 1071-1081. http://dx.doi.org/10.1002/jid.2888

Kolmannskog, V. (2012b). Gaps in Geneva, gaps on the ground: Case studies of Somalis displaced to Kenya and Egypt during the 2011 drought. New Issues in Refugee Research, 248. Geneva: United Nations High Commissioner for Refugees.

Leighton, M. (2006). Desertification and Migration. In P.M. Johnson, K. Mayrand \& M. Paquin (Eds.), Governing Global Desertification: Linking Environmental Degradation, Poverty and Participation. Aldershot: Ashgate. http://dx.doi.org/10.1111/j.1467-9388.2008.598_2.x

Lindley, A. (2011). Between a Protracted and a Crises Situation: Policy Responses to Somali Refugees in Kenya. Refugee Survey Quarterly, 30(4), 14-39. http://dx.doi.org/10.1093/rsq/hdr013

Mathiesen, T. (2005). Retten i samfunnet. Oslo: Paxforlag.

Nansen Initiative. (2013).The Nansen Initiative: Towards a "Protection Agenda" for people displaced across borders due to natural disasters and the adverse effects of climate change. Retrieved from http://www.nanseninitiative.org/

O’Brien, K. L., Eriksen, S., Nygaard, L., \& Schjolden, A. (2007). Why different interpretations of vulnerability matter in climate change discourses. Climate Policy, 7(1), 73-88. http://dx.doi.org/10.1080/14693062.2007.9685639

Rankin, M. B. (2005). Extending the limits or narrowing the scope? Deconstructing the OAU refugee definition thirty years on. New Issues in Refugee Research, 113. Geneva: United Nations High Commissioner for Refugees.

Refugee Consortium of Kenya. (2012). Asylum Under Threat: Assessing the protection of Somali refugees in Dadaab refugee camps and along the migration corridor. Nairobi: Pann Printers Ltd.

Regional Mixed Migration Secretariat. (2013). Migrant smuggling in the Horn of Africa and Yemen. The political economy and protection risks. Mixed migration research series, 1. Nairobi: Regional Mixed Migration Secretariat.

United Nations High Commissioner for Refugees. (2012). More than 1,500 drown or go missing trying to cross the Mediterranean in 2011.News story, 31 January 2012.Retrieved from www.unhcr.org/4f2803949.html

United Nations International Strategy for Disaster Reduction. (2009). Terminology. Retrieved from http://www.unisdr.org/we/inform/terminology

Zetter, R. (2011). Protecting Environmentally Displaced People: Developing the Capacity of Legal and Normative Frameworks. Refugee Studies Centre: Oxford University.

\section{$(\mathrm{cc})$ EY}

This work is licensed under a Creative Commons Attribution 3.0 License. 